\title{
Nitrogen fixation rates and controls at Stn ALOHA
}

\author{
M. N. W. Grabowski, M. J. Church, D. M. Karl* \\ Department of Oceanography, University of Hawaii, Honolulu, Hawaii 96822, USA
}

\begin{abstract}
Rates of dinitrogen $\left(\mathrm{N}_{2}\right)$ fixation were measured at Stn ALOHA in the North Pacific Subtropical Gyre (NPSG) on 9 cruises during the period April 2004 to March 2005. On each cruise, a near-surface $(5 \mathrm{~m})$ seawater sample was incubated with ${ }^{15} \mathrm{~N}$-labeled $\mathrm{N}_{2}$ under simulated in situ conditions for $24 \mathrm{~h}$ prior to filtration of either whole water or $<10 \mu \mathrm{m}$ filtrate on microfine $(0.7 \mu \mathrm{m}$ nominal porosity) glass fiber filters; on 3 cruises, surface to $125 \mathrm{~m}$ depth profiles of size-fractionated $\mathrm{N}_{2}$ fixation rates were also obtained. Nearly all (on average $95 \%$ ) of the net $\mathrm{N}_{2}$ fixation in the euphotic zone occurred in the upper $75 \mathrm{~m}$, and was mostly $(64 \pm 5$ [SE]\%) contained in the $<10 \mu \mathrm{m}$ size fraction following a $24 \mathrm{~h}$ incubation period. Highest surface diazotroph activity at this site was observed in July to August (1.63 to $1.68 \mu \mathrm{mol} \mathrm{N} \mathrm{m}{ }^{-3} \mathrm{~d}^{-1}$ ) and lowest $\mathrm{N}_{2}$ fixation rates occurred in September to Novem-

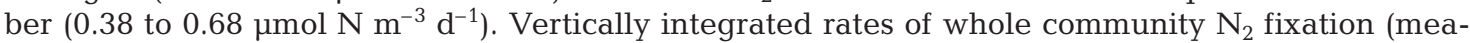
sured in November, February and March) varied 5-fold (20.2 to $\left.109 \mu \mathrm{mol} \mathrm{N} \mathrm{m}^{-2} \mathrm{~d}^{-1}\right)$. The short-term response of the microbial community to the addition of iron ( $\mathrm{Fe}$ ) and/or phosphorus (P) was variable, suggesting that contemporaneous $\mathrm{N}_{2}$ fixation at Stn ALOHA may be controlled by the population dynamics of the various diazotroph species rather than by instantaneous resource limitation.
\end{abstract}

KEY WORDS: Nitrogen fixation · Diazotroph · Stn ALOHA · North Pacific gyre

Resale or republication not permitted without written consent of the publisher

\section{INTRODUCTION}

In nitrogen $(\mathrm{N})$-limited ecosystems, 'new' production is fueled by allochthonous inputs of $\mathrm{N}$ including upward eddy diffusion of nitrate $\left(\mathrm{NO}_{3}^{-}\right)$from beneath the euphotic zone and dinitrogen $\left(\mathrm{N}_{2}\right)$ fixation within the euphotic zone (Dugdale \& Goering 1967). In contrast, 'regenerated' production is supported by locally recycled $\mathrm{N}$ including the products of excretion/exudation, grazing, viral lysis, death/autolysis, organic matter decomposition and nitrification. In most open ocean ecosystems, new production is a relatively minor portion $(\leq 10$ to $15 \%)$ of total production and until recently was thought to be supported exclusively by $\mathrm{NO}_{3}{ }^{-}$(Eppley \& Peterson 1979). This paradigm, especially the quantitative significance of $\mathrm{N}_{2}$ fixation in new production, is beginning to change (Karl et al. 1997, Capone et al. 2005). Evidence for the contribution of $\mathrm{N}_{2}$ fixation in the global marine environment derives from geochemical tracers that integrate over long timescales and large spatial scales, as well as from biological measurements that track contemporary, local proces- ses. Geochemical tracers include natural ${ }^{15} \mathrm{~N}$ isotope distributions and mass balances (Saino \& Hattori 1980, Karl et al. 1997, Dore et al. 2002), anomalous N to phosphorus (P) ratios of subeuphotic-zone inorganic nutrient pools (Michaels et al. 1996, Deutsch et al. 2007), dissolved inorganic carbon (DIC) drawdown in the absence of $\mathrm{NO}_{3}{ }^{-}$(Michaels et al. 1994) and temporal dynamics of soluble reactive P pools (Karl \& Tien 1997, Karl 2007). Biological tracers include enumeration of putative $\mathrm{N}_{2}$-fixing microorganisms (Capone et al. 1997, Zehr et al. 2001), field measurements of $\mathrm{N}_{2}$ fixation using either the acetylene reduction technique or ${ }^{15} \mathrm{~N}$ labeled $\mathrm{N}_{2}$ (Dore et al. 2002, Montoya et al. 2004), and measurements of the genetic potential for $\mathrm{N}_{2}$ fixation (Zehr et al. 1998, Church et al. 2005). Collectively, these data sets provide a robust substantiation for the importance of $\mathrm{N}_{2}$ fixation in the global marine $\mathrm{N}$ cycle. In addition to enhancing productivity, $\mathrm{N}_{2}$ fixation can impact the decoupling of carbon (C), N and P cycles, the $\mathrm{C}: \mathrm{N}: \mathrm{P}$ stoichiometry of exported organic matter and net $\mathrm{C}$ sequestration to the deep sea. Many of these data sets were collected during the Hawaii Ocean 
Time-series (HOT) program at its deep-ocean Stn ALOHA (A Long-term Oligotrophic Habitat Assessment $\left(22^{\circ} 45^{\prime} \mathrm{N}, 158^{\circ} \mathrm{W}\right)$ in the North Pacific Subtropical Gyre (NPSG) where systematic changes in physical and biogeochemical habitat variability can be observed despite natural ecosystem variability.

Herein we report near-surface water $\mathrm{N}_{2}$ fixation rates during an annual cycle (April 2004 to March 2005) and provide an assessment of the vertical structure of diazotroph activity (November, February, March) at Stn ALOHA. This research clarifies the importance of quantifying diazotrophic activity of whole microbial community assemblages. Using isotope mass balance and N:P stoichiometry, Karl et al. (1997) suggested that Trichodesmium spp. supported one-quarter to one-half of the new production at Stn ALOHA. The discovery of small $(<10 \mu \mathrm{m})$ diazotrophs (Zehr et al. 1998) and subsequent measurement of $\mathrm{N}_{2}$ fixation in this size class (Dore et al. 2002, Montoya et al. 2004, Holl et al. 2007) illustrates the need to assess the variable rates and metabolic responses of large and small diazotrophs. Potential controls on $\mathrm{N}_{2}$ fixation were also investigated using nutrient $(\mathrm{P}, \mathrm{Fe})$ manipulation incubation experiments.

\section{MATERIALS AND METHODS}

Station location and sampling protocols. All sampling and measurements were performed in conjunction with the HOT program at Stn ALOHA. Water column sampling was conducted using a Sea-Bird CTD sensor package (conductivity, temperature, depth, fluorescence, dissolved oxygen) that was integrated with a 24-position pylon, aluminum-framed rosette sampler equipped with 121 PVC water sampling bottles. Samples were taken on HOT cruises 158 to 159 (April to May 2004), 161 to 165 (July to November 2004) and 167 to 168 (February to March 2005), which covers 1 annual cycle from April 2004 to March 2005.

Nitrogen fixation rate measurements and experimental manipulations. A ${ }^{15} \mathrm{~N}$ isotopic tracer method (Montoya et al. 1996, Capone \& Montoya 2001) was used to measure $\mathrm{N}_{2}$ fixation rates. During the majority of cruises in the present study, whole water samples ( $\sim 1$, no pre-screening) were incubated in 4.71 acidwashed Tedlar gas sampling bags fitted with gas-tight Teflon-backed septa. For HOT cruises 167 and 168, 4.51 polycarbonate bottles were filled to overflowing with whole water samples and sealed using caps that were fitted with thick, silicone septa. Exactly $1 \mathrm{ml}$ of ${ }^{15} \mathrm{~N}_{2}$ gas (99\%, Isotech) was injected into each sample bag or bottle using a gas-tight syringe and stainless steel needle. For each sampling occasion and at each depth sampled, a parallel, unincubated sample was processed, as is required to calculate $\mathrm{N}_{2}$ fixation rates. For depth profiles, samples were incubated in a 3chambered deck incubator designed to control both temperature and light quality and quantity. For the 3 cruises during which depth profiles were obtained (November, February and March), the temperatures in the upper $125 \mathrm{~m}$ were 20.6 to $26.6^{\circ} \mathrm{C}, 21.6$ to $24.0^{\circ} \mathrm{C}$ and 20.9 to $24.2^{\circ} \mathrm{C}$, and the incubation temperatures were set at 21 to $26^{\circ} \mathrm{C}, 21$ to $26^{\circ} \mathrm{C}$ and 22 to $24^{\circ} \mathrm{C}$, with an average difference between ambient and incubated temperature of $0.7^{\circ} \mathrm{C}$. Water samples were grouped to best match the temperatures and light levels of their depth of origin.

During several cruises, nutrient addition experiments were performed with surface seawater to determine the effect of $\mathrm{P}$ and $\mathrm{Fe}$ on $\mathrm{N}_{2}$ fixation rates. $\mathrm{P}$ $\left(\mathrm{K}_{2} \mathrm{HPO}_{4}\right)$ and $\mathrm{Fe}\left(\mathrm{FeCl}_{2}\right)$ were added to final concentrations ranging from 170 to $360 \mathrm{nM}$ and $2 \mathrm{nM}$, respectively, either as single nutrient enrichments or combinations. Because stringent trace metal clean procedures were not employed, this study is only able to assess the response of diazotrophy relative to a control treatment, with each treatment having presumably equal, but unquanitified, Fe contamination.

Size fractionation. To determine the size distribution of the assimilation of ${ }^{15} \mathrm{~N}_{2}$, samples from selected profiles and nutrient perturbation experiments (all samples from November, February and March) were sizefractionated following a $24 \mathrm{~h}$ whole water incubation. Two treatments were prepared: (1) whole water filtered onto a combusted GFF filter (Total) and (2) a $10 \mu \mathrm{m}$ Nitex mesh filtrate also filtered onto a GFF filter $(<10 \mu \mathrm{m}) . \mathrm{N}_{2}$ fixation in the large $(>10 \mu \mathrm{m})$ size fraction was calculated as the difference between these 2 measurements $(>10 \mu \mathrm{m}=$ Total $-(<10 \mu \mathrm{m}))$. The GFF filters were stored frozen $\left(-20^{\circ} \mathrm{C}\right)$ until preparation for analysis by mass spectrometry.

Sample processing and data reporting. Filters were dried at $60^{\circ} \mathrm{C}$ and pelleted for analysis using a CarloErba Elemental Analyzer NC2500 interfaced with a Finnigan delta $\mathrm{S}$ ion ratio-monitoring mass spectrometer via a Finnigan ConFlow-II to determine particulate nitrogen (PN) mass and stable isotopic composition of the PN $\left(\delta^{15} \mathrm{~N}-\mathrm{PN}\right)$. All nitrogen isotopic data are presented in standard delta notation:

$$
\delta^{15} \mathrm{~N}_{\text {sample }}=\left\{\left[\frac{\left({ }^{15} \mathrm{~N} /{ }^{14} \mathrm{~N}\right)_{\text {sample }}}{\left({ }^{15} \mathrm{~N} /{ }^{14} \mathrm{~N}\right)_{\text {standard }}}\right]-1\right\} \times 1000
$$

Atmospheric $\mathrm{N}_{2}$ gas is the reference standard $\left({ }^{15} \mathrm{~N} /{ }^{14} \mathrm{~N}=0.0036765, \delta^{15} \mathrm{~N}=0 \%\right.$ o). At each depth sampled, $\mathrm{N}_{2}$ fixation rates were determined from PN mass and $\delta^{15} \mathrm{~N}-\mathrm{PN}$ of incubated samples, the $\delta^{15} \mathrm{~N}-\mathrm{PN}$ of unincubated samples ( $\mathrm{T}_{0}$ samples), ambient dissolved $\mathrm{N}_{2}$ concentration, and atom percent enrichment due to the addition of ${ }^{15} \mathrm{~N}_{2}$ (Montoya et al. 1996). Unincubated 
samples represent natural abundance PN concentration and $\delta^{15} \mathrm{~N}-\mathrm{PN}$ of the depth sampled. The detection limit of this assay with respect to the analytical capabilities of the instruments used is $0.06 \mu \mathrm{mol} \mathrm{N} \mathrm{m}^{-3} \mathrm{~d}^{-1}$. This value was calculated for the smallest PN masses sampled, using twice the conservative upper estimate of instrument precision (twice $0.8 \%$ ). Additionally, the detection limit of this assay calculated from twice the average standard error of triplicate $T_{0}$ values (twice $0.32 \%$ ) and an average PN mass sampled is $0.03 \mu \mathrm{mol}$ $\mathrm{N} \mathrm{m}{ }^{-3} \mathrm{~d}^{-1}$.

The results from the nutrient addition experiments are reported as percent changes calculated as the $\mathrm{N}_{2}$ fixation rate of the nutrient-treated samples relative to that of the control treatment expressed as percent change:

$$
\begin{aligned}
\% \text { change }= & \left\{\left[\left(\mathrm{N}_{2} \text { fixation }\right)_{\text {treatment }}-\left(\mathrm{N}_{2} \text { fixation }\right)_{\text {control }}\right]\right. \\
& \left./\left(\mathrm{N}_{2} \text { fixation }\right)_{\text {control }}\right\} \times 100
\end{aligned}
$$

Differences in the response to nutrient amendments were analyzed using a 1-way ANOVA with Tukey's post hoc test. Model 1 linear regression analysis was used to assess correlation. All statistical tests were performed using $\mathrm{p}<0.05$ as a criterion for significance. Statistical analyses were performed using either Excel (Microsoft) for simple $t$-tests and regression analyses or MINITAB Statistical Software for ANOVA with Tukey's test.

Ancillary measurements. Soluble reactive phosphorus (SRP) was routinely measured using standard HOT program protocols (for complete HOT protocols, see http://hahana.soest.hawaii.edu/hot/methods/results. html). Seawater was collected in acid-washed, highdensity polyethylene bottles from known depths using the CTD-rosette sampler. Samples were stored frozen until analyzed using the magnesium-induced coprecipitation (MAGIC) method (Karl \& Tien 1992). SRP inventory turnover time was calculated using P uptake estimated from depth integrated (0 to $100 \mathrm{~m}$ ) primary production (calculated from $12 \mathrm{~h}$ in situ ${ }^{14} \mathrm{C}$ uptake experiments) and assuming a C:P molar ratio of 100:1 (idealized plankton; Karl \& Yanagi 1997).

Phycoerythrin, an accessory pigment found in cyanobacteria, was determined in 3 size classes (>10 $\mu \mathrm{m}, 5.0$ to $10 \mu \mathrm{m}$, and 0.4 to $5.0 \mu \mathrm{m}$ ) using the in vivo glycerol-uncoupling method on each cruise (Dore et al. 2002). With many marine diazotrophs being cyanobacteria (although not all cyanobacteria are diazotrophs), phycoerythrin was used as a relative indicator of cyanobacteria abundance in the larger size fractions $(>5.0 \mu \mathrm{m})$. Trichodesmium spp., unicellular diazotrophic cyanobacteria such as Crocosphaera spp., and endosymbiotic nitrogen fixers possess this accessory pigment. For these measurements, samples were pressure-filtered sequentially through $10 \mu \mathrm{m}$ Nitex mesh followed by a $5.0 \mu \mathrm{m}$ polycarbonate filter. A portion of the filtrate (1 l) was vacuum-filtered onto a $0.4 \mu \mathrm{m}$ polycarbonate filter. Each filter was placed in a $20 \mathrm{ml}$ glass scintillation vial containing equal volumes of seawater and glycerol. Samples were placed on a shaker table to dislodge cells from the filter. Phycoerythrin fluorescence was measured on a Turner Designs TD700 fluorometer calibrated using commercial $\beta$-phycoerythrin standard (Cyanotech) with $544 \mathrm{~nm}$ (excitation) and $577 \mathrm{~nm}$ (emission) wavelength filters.

Samples for microscopy-based enumeration of phycoerythrin-containing cells were fixed with $2 \%$ formalin. Various sample volumes (100 to $300 \mathrm{ml}$ ) were vacuum-filtered onto black polycarbonate filters $(0.22 \mu \mathrm{m})$ to achieve optimal cell density (5 to 20 cells per field enumerated). Two categories of phycoerythrin-containing cyanobacteria were enumerated (at $100 \times$ ) under an excitation wavelength of 510 to $560 \mathrm{~nm}$ : Synechococcus spp. and Crocosphaera-like (3 to $8 \mu \mathrm{m}$ diameter, coccoid cells). Trichodesmium spp. and freeliving Richelia spp. abundances were also recorded when observed.

\section{RESULTS}

\section{Depth distribution and temporal variability of $\mathbf{N}_{2}$ fixation measurements}

Depth profiles of $\mathrm{N}_{2}$ fixation from November, February and March revealed significant variability within the euphotic zone. In each profile, highest activity was near the surface and rates decreased with increasing water depth to below detection $\left(\leq 0.03 \mu \mathrm{mol} \mathrm{N} \mathrm{m}^{-3} \mathrm{~d}^{-1}\right)$ at approximately $75 \mathrm{~m}$ (Fig. 1). The cumulative contribution of $\mathrm{N}_{2}$ fixation as a function of depth also illustrates that euphotic zone diazotrophy was nearsurface-dominated (Fig. 2). At all depths sampled, the majority (mean $64 \pm 5$ [SE] \%, range 31 to $100 \%$ ) of net $\mathrm{N}_{2}$ fixed was found in the $<10 \mu \mathrm{m}$ fraction (Table 1). Depth-integrated rates (0 to $125 \mathrm{~m}$ ) indicated that the lowest $\mathrm{N}_{2}$ fixation rates occurred in November

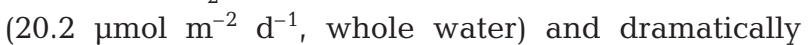
higher rates occurred in March $\left(109 \mu \mathrm{mol} \mathrm{m} \mathrm{m}^{-2} \mathrm{~d}^{-1}\right.$, whole water). In these profiles, depth trends of the size distribution of $\mathrm{N}_{2}$ fixed do not parallel size-fractionated phycoerythrin concentrations $(0.4$ to $5.0 \mu \mathrm{m}$ and 5.0 to $10.0 \mu \mathrm{m}$ ) or microscopy counts of Crocosphaera-like cells (data not shown). Surface $\mathrm{N}_{2}$ fixation rates were determined in whole water over the course of the sampling period (April to March) (Fig. 3). Highest diazotroph activity was observed in July and August (1.63 to $1.68 \mu \mathrm{mol} \mathrm{N} \mathrm{m}^{-3} \mathrm{~d}^{-1}$ ) and the maximum rate measured occurred in March. Consistently lower $\mathrm{N}_{2}$ fixation rates ( 0.38 to $\left.0.68 \mu \mathrm{mol} \mathrm{N} \mathrm{m}^{-3} \mathrm{~d}^{-1}\right)$ were observed 


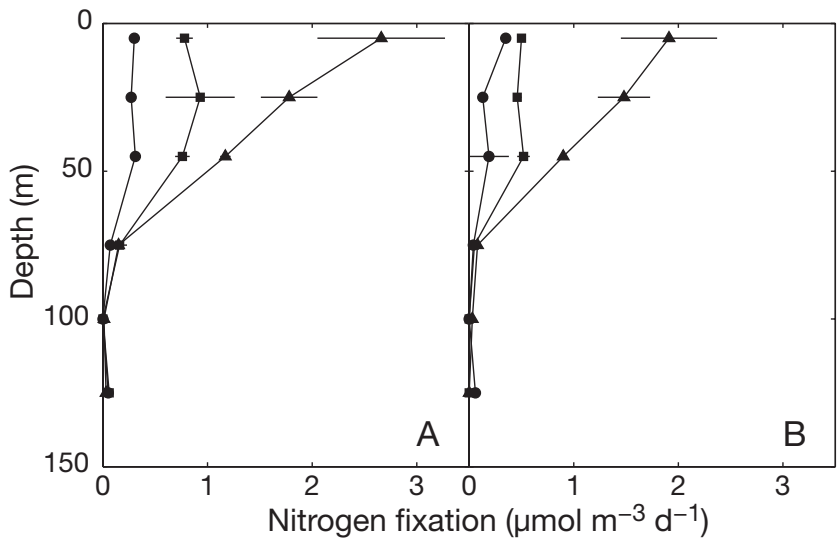

Fig. 1. Depth profiles of (A) whole-water and (B) size-fractionated $(<10 \mu \mathrm{m}) \mathrm{N}_{2}$ fixation rates during November $2004(\mathbf{)})$, February 2005 (ם) and March 2005 (\). Error bars are SE ( $\mathrm{n}=3$, where samples replicated)

during September to November, with the lowest rate in October.

The background ${ }^{15} \mathrm{~N}$ isotopic abundance of the suspended particulate matter collected at $5 \mathrm{~m}$ showed a systematic seasonal trend with isotopically enriched values $\left(\delta^{15} \mathrm{~N} \geq 2 \%\right.$ ) in the winter when $\mathrm{N}_{2}$ fixation rates are at their minimum, to maximum depletions $\left(\delta^{15} \mathrm{~N}=\right.$ -1 to $-2 \%$ ) in summer. These observations are consistent with an enhanced summertime supply of $\mathrm{N}$ via $\mathrm{N}_{2}$ fixation (Fig. 3).

Table 1. $\mathrm{N}_{2}$ fixation rates (mean $\pm \mathrm{SE}, \mathrm{n}=3$ [when samples replicated]; $\mu$ mol $\mathrm{N}$ $\mathrm{m}^{-3} \mathrm{~d}^{-1}$ ) in the upper portion of the water column (0 to $75 \mathrm{~m}$ ) at Stn ALOHA. Rates were measured using ${ }^{15} \mathrm{~N}_{2}$ tracer, and size-fractionated following a $24 \mathrm{~h}$ incubation. DL = detection limit of $0.03 \mu \mathrm{mol} \mathrm{m}{ }^{-3} \mathrm{~d}^{-1}$

\begin{tabular}{|c|c|c|c|c|}
\hline \multirow{2}{*}{$\begin{array}{l}\text { Depth } \\
\text { (m) }\end{array}$} & \multirow{2}{*}{$\begin{array}{l}\text { Whole } \\
\text { water }\end{array}$} & \multicolumn{2}{|c|}{ Size fraction } & \multirow{2}{*}{$\begin{array}{l}\text { Contribution of } \\
<10 \mu \mathrm{m} \text { size } \\
\text { fraction }(\%)\end{array}$} \\
\hline & & $<10 \mu \mathrm{m}$ & $>10 \mu \mathrm{m}$ & \\
\hline \multicolumn{5}{|l|}{ HOT-165 (Nov 2004) } \\
\hline 5 & 0.30 & 0.35 & $<\mathrm{DL}$ & 100 \\
\hline 25 & $0.27 \pm 0.01$ & $0.13 \pm 0.02$ & $0.14 \pm 0.02$ & 48 \\
\hline 45 & $0.31 \pm 0.04$ & $0.19 \pm 0.19$ & $0.12 \pm 0.19$ & 61 \\
\hline 75 & $0.07 \pm 0.02$ & $0.04 \pm 0.02$ & $0.03 \pm 0.03$ & 57 \\
\hline Depth -integrated rate & 20.2 & 14.5 & 6.9 & \\
\hline \multicolumn{5}{|l|}{ HOT-167 (Feb 2005) } \\
\hline 5 & $0.78 \pm 0.08$ & $0.50 \pm 0.01$ & $0.28 \pm 0.08$ & 64 \\
\hline 25 & $0.93 \pm 0.33$ & $0.46 \pm 0.04$ & $0.47 \pm 0.33$ & 49 \\
\hline 45 & $0.76 \pm 0.07$ & $0.52 \pm 0.06$ & $0.24 \pm 0.09$ & 68 \\
\hline 75 & $0.16 \pm 0.04$ & $0.05 \pm 0.03$ & $0.11 \pm 0.05$ & 31 \\
\hline Depth-integrated rate & 54.4 & 31.1 & 23.4 & \\
\hline \multicolumn{5}{|l|}{ HOT-168 (Mar 2005) } \\
\hline 5 & $2.66 \pm 0.61$ & $1.91 \pm 0.46$ & $0.75 \pm 0.76$ & 72 \\
\hline 25 & $1.78 \pm 0.27$ & $1.48 \pm 0.25$ & $0.30 \pm 0.37$ & 83 \\
\hline 45 & $1.17 \pm 0.05$ & $0.90 \pm 0.02$ & $0.27 \pm 0.05$ & 77 \\
\hline 75 & $0.15 \pm 0.08$ & $0.08 \pm 0.01$ & $0.07 \pm 0.08$ & 53 \\
\hline Depth-integrated rate & 109 & 83.7 & 26.3 & \\
\hline
\end{tabular}

\section{SRP variability}

The temporal variability in surface SRP concentrations was similar to that observed in $\mathrm{N}_{2}$ fixation rates between April and March (Fig. 3). Highest recorded SRP concentrations during this time precede a 2 mo period of relatively high $\mathrm{N}_{2}$ fixation rates in the surface water. The lowest surface SRP concentrations, occurring in October and November (6.1 to $9.9 \mathrm{nM}$ ), are concurrent with the lowest measured diazotroph activity.

SRP turnover time during this $1 \mathrm{yr}$ study period varied from 2.1 to $14.8 \mathrm{~d}$. There is a substantial, positive but non-significant correlation between $\mathrm{SRP}$ turnover time and surface $\mathrm{N}_{2}$ fixation rates $\left(\mathrm{r}^{2}=0.39, \mathrm{p}=0.07\right)$.

\section{Nutrient amendment experiments}

To determine the effect of $\mathrm{P}$ addition on $\mathrm{N}_{2}$ fixation rates, experiments were performed on 7 of the 9 cruises included in the present study. Variable concentrations of P (160 to $320 \mathrm{nM}$ $\mathrm{PO}_{4}$ ) were added during these experiments. The diazotroph response to $\mathrm{P}$ enrichment varied between cruises (Table 2). Although substantial increases in $\mathrm{N}_{2}$ fixation rates were occasionally observed upon addition of P (October, November, February, March), no response was statistically significant relative to control treatments based on $t$-tests $(\mathrm{p}<0.05)$ and ANOVA. 


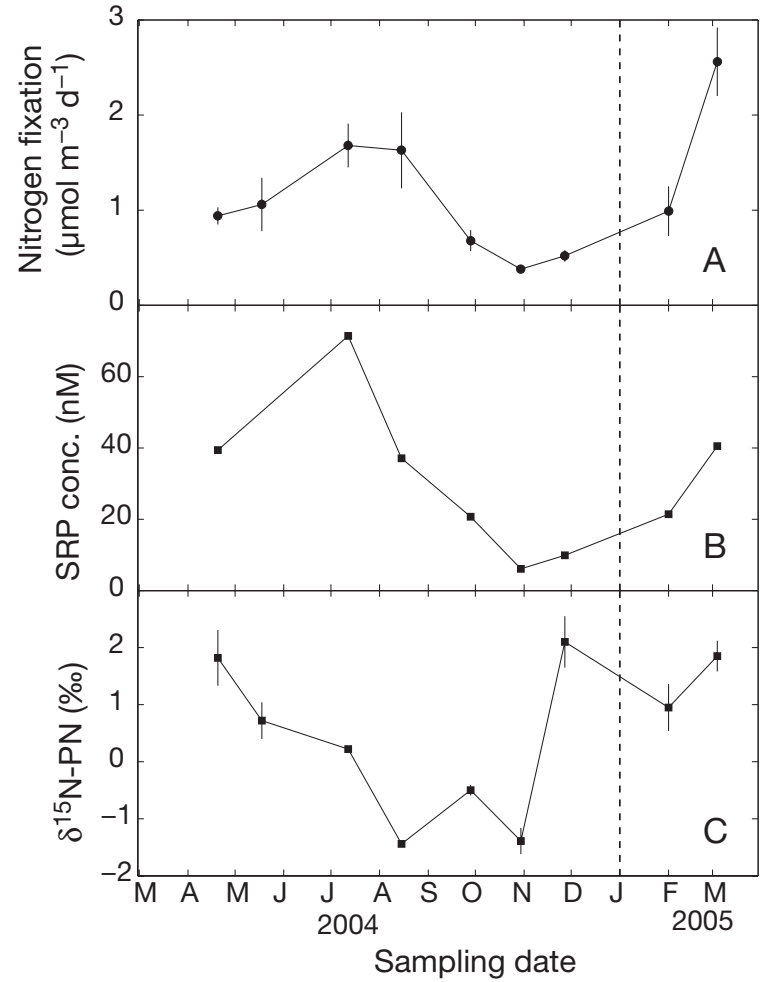

Fig. 3. (A) Surface (5 m) $\mathrm{N}_{2}$ fixation rates, (B) soluble reactive phosphorus (SRP) concentration and (C) suspended $\delta^{15} \mathrm{~N}-\mathrm{PN}$ (particulate nitrogen) from April 2004 to March 2005. Error bars in $(A)$ and $(C)$ are SE $(n=3)$. The vertical dashed line marks the end of 2004

On the November, February and March cruises, Fe addition experiments were conducted. No significant increase in $\mathrm{N}_{2}$ fixation rate relative to control incubations was observed in Fe (2.0 nM added) or combined Fe and $\mathrm{P}(2.0 \mathrm{nM} \mathrm{Fe}$ and $160 \mathrm{nM} \mathrm{P}$ added $)$ treatments in whole water or in the $<10 \mu \mathrm{m}$ size fraction in November. However, identical manipulations in February revealed significantly enhanced $\mathrm{N}_{2}$ fixation in whole water and in the $<10 \mu \mathrm{m}$ size fraction for both $\mathrm{Fe}$

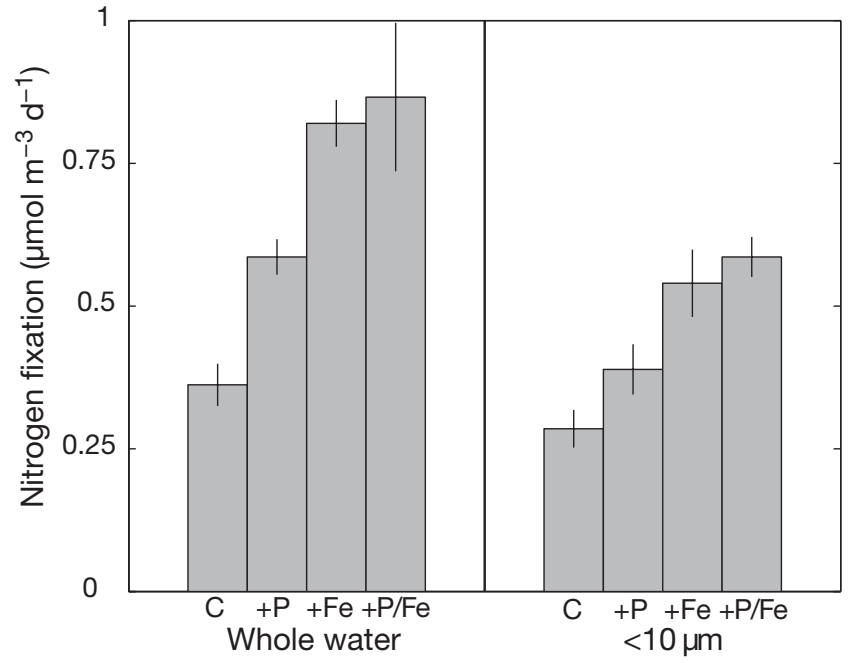

Fig. 4. $\mathrm{N}_{2}$ fixation rates in control, $+\mathrm{P},+\mathrm{Fe}$, and $+\mathrm{P} / \mathrm{Fe}$ treatments for whole-water and $<10 \mu \mathrm{m}$ size fraction diazotrophs from the February 2005 manipulation experiment. Error bars are $\operatorname{SE}(\mathrm{n}=3)$

and $\mathrm{Fe}+\mathrm{P}$ treatments, relative to control incubations (Fig. 4). Whole water incubations amended with Fe showed significant increases in $\mathrm{N}_{2}$ fixation rates, averaging $128 \%$ above control treatments (ANOVA, p < 0.05). Additions of $\mathrm{Fe}$ and $\mathrm{P}$ to whole water also resulted in significant increases of $142 \%$ (ANOVA, p < 0.05). Incorporation of ${ }^{15} \mathrm{~N}$ into the $<10 \mu \mathrm{m}$ size fraction increased 86 and $100 \%$ with addition of $\mathrm{Fe}$ and $\mathrm{Fe}+\mathrm{P}$, respectively (both increases significant, ANOVA, p < 0.05). In the March enrichment experiment, whole water and $<10 \mu \mathrm{m}$ size fraction both showed increased $\mathrm{N}_{2}$ fixation rates with $\mathrm{Fe}$ addition (32 and $37 \%$, respectively), and no increase with $\mathrm{Fe}$ and $\mathrm{P}$ addition (Fig. 5). Statistical significance of these increases (March experiment) could not be assessed due to lack of replication.
Table 2. Summary of whole-water P-addition experiments. Where $\pm \mathrm{SE}$ is shown, $\mathrm{n}=3$. $\mathrm{SRP}=$ soluble reactive phosphorus, $\mathrm{NF}=$ nitrogen fixation, na $=$ not available

\begin{tabular}{|lcccccc|}
\hline Date & $\begin{array}{c}\text { Ambient } \\
\text { SRP (nM) }\end{array}$ & $\begin{array}{c}\text { Average } \\
\text { added P } \\
(\mathrm{nM})\end{array}$ & $\begin{array}{c}\text { Total P } \\
(\mathrm{nM})\end{array}$ & $\begin{array}{c}\% \mathrm{P} \\
\text { added }\end{array}$ & $\begin{array}{c}\text { Control } \\
\mathrm{NF} \text { rate } \\
\left(\mu \mathrm{mol} \mathrm{m}^{-3} \mathrm{~d}^{-1}\right)\end{array}$ & $\begin{array}{c}+\mathrm{PO}_{4} \\
\mathrm{NF}_{\mathrm{mate}} \\
\left(\mu \mathrm{mol} \mathrm{m}^{-3} \mathrm{~d}^{-1}\right)\end{array}$ \\
\hline May 2004 & na & 264 & na & na & $0.43 \pm 0.12$ & $0.48 \pm 0.03$ \\
Jul 2004 & 71.4 & 168 & 239 & 140 & 1.68 & 1.56 \\
Aug 2004 & 37.1 & 157 & 194 & 320 & $1.63 \pm 0.40$ & $1.72 \pm 0.22$ \\
Oct 2004 & 6.1 & 174 & 180 & 2750 & $0.38 \pm 0.03$ & 0.71 \\
Nov 2004 & 9.9 & 160 & 170 & 1520 & $0.60 \pm 0.11$ & 1.07 \\
Feb 2005 & 21.4 & 160 & 181 & 650 & $0.36 \pm 0.04$ & $0.59 \pm 0.03$ \\
Mar 2005 & 40.5 & 160 & 201 & 300 & 2.87 & 2.96 \\
Mar 2005 & 40.5 & 320 & 361 & 690 & 2.87 & 3.73 \\
\hline
\end{tabular}

\section{DISCUSSION}

In N-limited oceanic regions like the NPSG, $\mathrm{N}_{2}$-fixing microorganisms would have a selective ecological advantage provided they have a source of energy and an available supply of other essential nutrients, especially $\mathrm{P}$ and Fe. At Stn ALOHA, the total $\mathrm{N}_{2}$ fixation rate is the product of the biomass of $\mathrm{N}_{2}$-fixing microbes and the biomass-specific rate of $\mathrm{N}_{2}$ fixation, each controlled by (solar) energy availability and nutrient availability. In each depth profile, highest $\mathrm{N}_{2}$ fixa- 


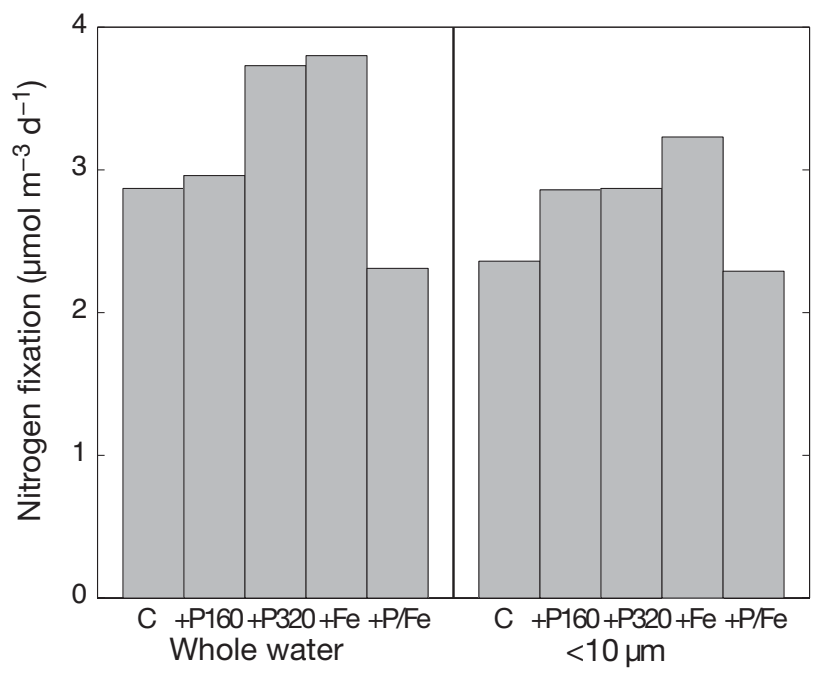

Fig. 5. $\mathrm{N}_{2}$ fixation rates in control (C), $+\mathrm{P} 160 \mathrm{nM},+\mathrm{P} 320 \mathrm{nM}$, $+\mathrm{Fe}$, and $+\mathrm{P} / \mathrm{Fe}$ treatments for whole-water and $<10 \mu \mathrm{m}$ size fraction diazotrophs from the March 2005 manipulation experiment

tion is present near the surface and the rates decrease to below the detection limit (detection limit $=0.03 \mu \mathrm{mol}$ $\mathrm{N} \mathrm{m}^{-3} \mathrm{~d}^{-1}$ ) at approximately $75 \mathrm{~m}$; an average of $95 \%$ of total diazotrophy takes place in the upper euphotic zone (0 to $75 \mathrm{~m}$; Figs. $1 \& 2$ ). This depth dependence of $\mathrm{N}_{2}$ fixation is consistent with the high energy requirement of diazotrophs (Karl et al. 2002). Solar energy photon fluxes at the $75 \mathrm{~m}$ depth horizon vary from approximately $1 \mathrm{~mol}$ quanta $\mathrm{m}^{-2} \mathrm{~d}^{-1}$ in winter to $>2 \mathrm{~mol}$ quanta $\mathrm{m}^{-2} \mathrm{~d}^{-1}$ in summer (Letelier et al. 2004). At greater depths, the systematic increase in fixed N, particularly nitrate, would also select against $\mathrm{N}$ acquisition via $\mathrm{N}_{2}$ fixation. Depth trends of the size distribution of $\mathrm{N}_{2}$ fixed do not parallel size-fractionated phycoerythrin concentrations $(0.4$ to $5.0 \mu \mathrm{m}$ and 5.0 to $10.0 \mu \mathrm{m}$, respectively) or microscopy counts of Crocosphaera-like cells (data not shown) suggesting that (1) not all diazotrophs contain phycoerythrin, (2) Crocosphaera-like cells may not be the dominant $\mathrm{N}_{2}$ fixers, (3) cell numbers or biomass cannot be used to estimate rates (i.e. variable $\mathrm{N}_{2}$ fixation rate per unit biomass) and/or (4) the ${ }^{15} \mathrm{~N}$ in the $<10 \mu \mathrm{m}$ size fraction may not be solely attributed to $\mathrm{N}_{2}$ fixation (i.e. it could be a consequence of 'secondary' labeling via excretion of ${ }^{15} \mathrm{NH}_{4}{ }^{+}$or ${ }^{15} \mathrm{~N}$-labeled dissolved organic nitrogen $\left[{ }^{15} \mathrm{~N}\right.$ DON]). Because diazotrophs require nearly an order of magnitude more Fe than photolithoautotrophs growing on ammonium (Kustka et al. 2003), the biomass of diazotrophs and therefore total rates of $\mathrm{N}_{2}$ fixation may be controlled by competition for Fe and P. The potential dependence of diazotrophy on Fe availability is highlighted in the February manipulation experiments in which $\mathrm{N}_{2}$ fixation increased 128 and $142 \%$ for whole water and 86 and $100 \%$ for the small $(<10 \mu \mathrm{m})$ size fraction above corresponding controls following addition of $\mathrm{Fe}$ and $\mathrm{Fe}+\mathrm{P}$, respectively (Fig. 4). However, the effect of the addition of P or Fe (or both) appeared to be variable perhaps due to the design of the field experiments or the complex dynamics of $\mathrm{P}$ and Fe or the availability of other essential nutrients. Consequently, further investigation is required to determine proximate and ultimate controls on diazotrophy at Stn ALOHA.

Although Trichodesmium spp. has been viewed as a dominant diazotroph in the open ocean (Capone et al. 1997), the post-incubation ${ }^{15} \mathrm{~N}$ incorporation in the present study indicates that labeling of the $<10 \mu \mathrm{m}$ size fraction is generally much greater than in the $>10 \mu \mathrm{m}$ fraction (mean $64 \pm 5$ [SE]\%; range 30 to $100 \%$ ). As mentioned previously, the labeling of $<10 \mu \mathrm{m}$ particulate matter with ${ }^{15} \mathrm{~N}$ is controlled by assimilation of ${ }^{15} \mathrm{~N}_{2}$ (i.e. $\mathrm{N}_{2}$ fixation) as well as uptake of recently released ${ }^{15} \mathrm{NH}_{4}{ }^{+}$or ${ }^{15} \mathrm{~N}$-DON from diazotrophs, which could affect the inferred size distribution of $\mathrm{N}_{2}$ fixation. The potential role of small, perhaps unicellular, diazotrophs at Stn ALOHA (also see Dore et al. 2002) presents a new paradigm for open ocean systems. Although other interpretations are also possible, a shift in the size structure of diazotrophy has large implications for the $\mathrm{N}$ cycle and for net $\mathrm{C}$ sequestration, as small cells may not sink as readily as large cells, such as diatoms that harbor diazotrophic cyanobacteria. Reduced sinking would result in decreased strength of the $\mathrm{N}_{2}$ fixationfueled C pump and, therefore, decreased C sequestration. As hypothesized by Karl et al. (2001), a downward shift in the planktonic size structure would also lead to a reduction of $\mathrm{C}$ supply to higher trophic levels and a longer residence time for $\mathrm{C}, \mathrm{N}$ and $\mathrm{P}$ in the euphotic zone due to increased dissolved organic matter (DOM) production. Indeed a significant increase in DOM inventory at Stn ALOHA from 1989 to 1999 has been observed (Church et al. 2002). While a climate-forced increase in ocean stability may explain the population shift and organic matter accumulation, this 'miniaturization' of diazotrophs may also be a response to nutrient (such as Fe or P) limitation.

$\mathrm{N}_{2}$ fixation rates presented here agree well with previous observations. From November to March, areal diazotroph activities in whole water and for the $<10 \mu \mathrm{m}$ size fraction are similar to other published rates from the North Pacific (Table 3). $\mathrm{N}_{2}$ fixation rates presented here from Stn ALOHA (whole water and $<10 \mu \mathrm{m}$ ) are also comparable to those observed in the tropical North Atlantic (Mahaffey et al. 2005). In addition, the temporal trend of $\mathrm{N}_{2}$ fixation at Stn ALOHA for the period of April to March is consistent with previously documented seasonality in which higher $\mathrm{N}_{2}$ fixation took place in the spring and summer months and lower 
Table 3. Summary of euphotic zone $\mathrm{N}_{2}$ fixation rate estimates in the North Pacific Ocean. ARA = acetylene reduction assay

\begin{tabular}{|c|c|c|}
\hline $\begin{array}{l}\text { Areal estimate } \\
\left(\mu \mathrm{mol} \mathrm{N} \mathrm{m}^{-2} \mathrm{~d}^{-1}\right)\end{array}$ & Method & Source \\
\hline \multicolumn{3}{|l|}{$<10 \mu \mathrm{m}$ size fraction } \\
\hline 92 & ${ }^{15} \mathrm{~N}_{2}$ & Zehr et al. (2001) \\
\hline $23 \pm 6$ & ${ }^{15} \mathrm{~N}_{2}$ & Dore et al. (2002) \\
\hline $66 \pm 19$ & ${ }^{15} \mathrm{~N}_{2}$ & Montoya et al. (2004) \\
\hline $43 \pm 21$ & ${ }^{15} \mathrm{~N}_{2}$ & Present study \\
\hline \multicolumn{3}{|l|}{ Whole water } \\
\hline $72 \pm 13$ & ${ }^{15} \mathrm{~N}_{2}$ & Dore et al. (2002) \\
\hline $61 \pm 26$ & ${ }^{15} \mathrm{~N}_{2}$ & Present study \\
\hline \multicolumn{3}{|l|}{ Trichodesmium spp. } \\
\hline 135 & ARA & Gundersen et al. (1976) \\
\hline 33 & ARA & Mague et al. (1977) \\
\hline $85-140$ & ARA & Karl et al. (1997) \\
\hline $53-143$ & ARA & Mahaffey et al. (2005) \\
\hline
\end{tabular}

activity was observed during winter (Dore et al. 2002). The natural variation in the abundance of the $2 \mathrm{~N}$ isotopes, ${ }^{14} \mathrm{~N}\left(99.64 \%\right.$ by atoms) and ${ }^{15} \mathrm{~N}(0.36 \%$ by atoms), can also be used to examine temporal variability in processes involved in the marine $\mathrm{N}$ cycle. For example, $\mathrm{N}_{2}$ fixation affects $\mathrm{PN}$ by adding largely ${ }^{14} \mathrm{~N}$ (dissolved atmospheric $\mathrm{N}_{2}$ ) and therefore depleting ${ }^{15} \mathrm{~N}$ in the newly formed particulate organic matter. Surface $\mathrm{N}_{2}$ fixation was high in July and August (1.63 to $1.68 \mu \mathrm{mol} \mathrm{N} \mathrm{m}^{-3} \mathrm{~d}^{-1}$ ) followed by the most depleted surface-suspended $\delta^{15} \mathrm{~N}-\mathrm{PN}(-1.44$ to $-0.5 \%)$ from August through October. Consistently low $\mathrm{N}_{2}$ fixation rates were observed from September through November $\left(0.38\right.$ to $\left.0.68 \mu \mathrm{mol} \mathrm{N} \mathrm{m} \mathrm{N}^{-3} \mathrm{~d}^{-1}\right)$, coincident with the heaviest recorded $\delta^{15} \mathrm{~N}-\mathrm{PN}$ of the surface-suspended PN (2.10\%; Fig. 3). The observed trends in $\mathrm{N}_{2}$ fixation and $\delta^{15} \mathrm{~N}-\mathrm{PN}$ are consistent with a contribution from $\mathrm{N}_{2}$ fixation. The temporal offset between $\mathrm{N}_{2}$ fixation and suspended $\delta^{15} \mathrm{~N}-\mathrm{PN}$ illustrates that $\mathrm{N}_{2}$ fixation contributes to large and dynamic $\mathrm{N}$ pools and that suspended $\delta^{15} \mathrm{~N}-\mathrm{PN}$ can also be affected by other processes such as recycling of $\mathrm{N}$ in the surface waters at Stn ALOHA (Checkley \& Miller 1989). $\mathrm{N}_{2}$ fixation has been shown to contribute new $\mathrm{N}$ on the order of that delivered via advection of $\mathrm{NO}_{3}{ }^{-}$from beneath the euphotic zone (Capone et al. 1997, Karl et al. 1997, Dore et al. 2002, Montoya et al. 2004). The rates measured in the present study, and in most other ${ }^{15} \mathrm{~N}$ uptake experiments, are probably minimum estimates because they do not track gross $\mathrm{N}_{2}$ fixation (Bronk et al. 1994). Any ${ }^{15} \mathrm{~N}_{2}$ reduced and subsequently added to the dissolved inorganic or dissolved organic pools will not be accounted for with the methods employed. There are also potential problems related to undersampling both in time and in space, because oceanic $\mathrm{N}_{2}$ fixation has been suggested to be an ephemeral phenomenon in open ocean ecosystems (Dore et al. 2008). Furthermore, if $\mathrm{N}_{2}$ fixation is supported by large organisms such as Trichodesmium spp. or endosymbiont-containing diatoms, then the conventional water collection methods used in the present study may have selected against them.

Experimental (Mills et al. 2004) and theoretical (Karl 2002, Kustka et al. 2003) evidence has been presented for the importance of $\mathrm{Fe}$ and $\mathrm{P}$ as controls on diazotrophy. Euphotic zone SRP decline of nearly $80 \%$ over the past decade at Stn ALOHA (Karl 2007) and observed diazotroph limitation by $\mathrm{P}$ in the Atlantic Ocean (Sañudo-Wilhelmy et al. 2001) emphasize the potential for $\mathrm{P}$ control of diazotroph activity. In addition, Boyle et al. (2005) provide data indicating that maximum (March to June) and minimum (July to January) dust delivery of Fe at Stn ALOHA occurs concurrently with our measured $\mathrm{N}_{2}$ fixation rate variability. Total dissolved $(<0.4 \mu \mathrm{m})$ Fe concentrations at Stn ALOHA $(0.2$ to $0.8 \mathrm{nM}$ ) may not be considered limiting to primary production throughout most of the year (Boyle et al. 2005). However, the presence of colloidal (0.02 to $0.4 \mu \mathrm{m}) \mathrm{Fe}$ suggests that not all 'total dissolved Fe' may be available for metabolism (Wu et al. 2001), which could lead to concentrations of available Fe that limit diazotroph activity.

There are several lines of evidence that support diazotroph dependence on P and Fe at Stn ALOHA. First, SRP dynamics indicate that $\mathrm{P}$ exerts control on $\mathrm{N}_{2}$ fixation rates. SRP concentration and $\mathrm{N}_{2}$ fixation rates were temporally coherent throughout the 1 yr study period (Fig. 3). Relatively high surface $\mathrm{N}_{2}$ fixation rates (July and August) occurred after the highest observed SRP concentrations; in contrast, the lowest surface SRP concentrations occurred with the lowest rates of $\mathrm{N}_{2}$ fixation. P-stressed plankton may cause more rapid turnover times of SRP inventories. Calculated SRP turnover time during April 2004 to March 2005 varied from 2.1 to $14.8 \mathrm{~d}$. The average SRP turnover time $(8 \mathrm{~d})$ during that same period is less than one-half of that calculated by Karl \& Yanagi (1997) during September 1991 to March 1992 (17 d). Two subsequent studies determined $\mathrm{P}$ turnover times, via ${ }^{32} \mathrm{P}$-uptake experiments, of 12 d during 1996-1997 (Björkman et al. 2000) and 6 d during 2000-2001 (Björkman \& Karl 2003). This overall progression to more rapid turnover times is consistent with the observed decrease in SRP at Stn ALOHA between these study periods, and the continued $\mathrm{P}$ requirement by diazotrophs and all other microbes. In an environment with increased competition for SRP, diazotrophs may likewise accelerate their turnover of SRP or enhance their use of dissolved organic phosphorus (DOP) which represents nearly $90 \%$ of the total dissolved $\mathrm{P}$ pool in the near-surface waters at Stn ALOHA (Karl \& Björkman 2002). Experi- 
ments conducted in the present study occasionally revealed substantial increases in $\mathrm{N}_{2}$ fixation upon $\mathrm{P}$ amendment. The variability in response relative to ambient SRP concentration (i.e. response to amendment during low SRP in October and November and during higher SRP in March) indicates that $\mathrm{P}$ alone does not continuously control diazotroph activity. Furthermore, treatments amended with $\mathrm{Fe}$ showed substantial and significant increases in $\mathrm{N}_{2}$ fixation. These observations support the hypothesis that, along with SRP dynamics, Fe availability plays a critical role in diazotroph activity at Stn ALOHA.

\section{CONCLUSIONS}

$\mathrm{N}_{2}$ fixation is important in the nutrient dynamics and productivity of the NPSG as evidenced by the substantial diazotroph activity throughout the year in the upper euphotic zone. Rates of $\mathrm{N}_{2}$ fixation at Stn ALOHA are controlled both by the biomass of $\mathrm{N}_{2}$ fixing microorganisms and the activity per unit biomass. Diazotroph biomass and biomass-specific rate are determined by nutrient dynamics, competition, natural selection and light levels. $\mathrm{N}_{2}$ fixation rates at Stn ALOHA display a seasonal pattern that mimics surface SRP concentrations and seasonal Fe delivery from the atmosphere, which impacts the biomass of $\mathrm{N}_{2}$ fixing microorganisms and ultimately the rates of $\mathrm{N}_{2}$ fixation. While we do not yet have a predictive framework for determining changes in $\mathrm{N}_{2}$ fixation, the data presented here help to delimit the number of factors controlling diazotrophy in the NPSG. In addition, by understanding the role of $\mathrm{P}$ and $\mathrm{Fe}$ in diazotroph variability, we may be better able to assess changing biogeochemistry in the oligotrophic ocean.

Acknowledgements. The authors thank the HOT scientists and staff and the captains and crew of RV 'Kaimikai-OKanaloa' and RV 'Wecoma'. We also gratefully acknowledge the helpful advice of C. Mahaffey and B. Popp, and constructive criticisms provided by D. Bronk and 3 anonymous reviewers. This work was generously supported by the U.S. National Science Foundation and the Gordon and Betty Moore Foundation.

\section{LITERATURE CITED}

Björkman KM, Karl DM (2003) Bioavailability of dissolved organic phosphorus in the euphotic zone at Station ALOHA, North Pacific Subtropical Gyre. Limnol Oceanogr 48:1049-1057

Björkman KM, Thomson-Bulldis AL, Karl DM (2000) Phosphorus dynamics in the North Pacific subtropical gyre. Aquat Microb Ecol 22:185-198

Boyle EA, Bergquist BA, Kayser RA, Mahowald N (2005) Iron, manganese, and lead at Hawaii Ocean Time-series station
ALOHA: temporal variability and an intermediate water hydrothermal plume. Geochim Cosmochim Acta 69: 933-952

Bronk DA, Gilbert PM, Ward BB (1994) Nitrogen uptake, dissolved organic nitrogen release, and new production. Science 265:1843-1846

Capone DG, Montoya JP (2001) Nitrogen fixation and denitrification. In: Paul J (ed) Methods in microbiology. Academic Press, New York, p 501-515

Capone DG, Zehr JP, Paerl HW, Bergman B, Carpenter EJ (1997) Trichodesmium, a globally significant marine cyanobacterium. Science 276:1221-1229

Capone DG, Burns JA, Montoya JP, Subramaniam A and others (2005) Nitrogen fixation by Trichodesmium spp.: an important source of new nitrogen to the tropical and subtropical North Atlantic Ocean. Global Biogeochem Cycles 19:GB2024

> Checkley DM Jr, Miller CA (1989) Nitrogen isotope fractionation by oceanic zooplankton. Deep-Sea Res 36:1449-1456

Church MJ, Ducklow HW, Karl DM (2002) Multiyear increases in the dissolved organic matter inventories at Station ALOHA in the North Pacific Subtropical Gyre. Limnol Oceanogr 47:1-10

Church MJ, Short CM, Jenkins BD, Karl DM, Zehr JP (2005) Temporal patterns of nitrogenase gene (nifH) expression in the oligotrophic North Pacific Ocean. Appl Environ Microbiol 71:5362-5370

Deutsch C, Sarmiento JL, Sigman DM, Gruber N, Dunne JP (2007) Spatial coupling of nitrogen inputs and losses in the ocean. Nature 445:163-167

Dore JE, Brum JR, Tupas LM, Karl DM (2002) Seasonal and interannual variability in sources of nitrogen supporting export in the oligotrophic subtropical North Pacific Ocean. Limnol Oceanogr 47:1595-1607

Dore JE, Letelier RM, Church MJ, Lukas R, Karl DM (2008) Summer phytoplankton blooms in the oligotrophic North Pacific Subtropical Gyre: historical perspective and recent observations. Prog Oceanogr 76:2-38

Dugdale RC, Goering JJ (1967) Uptake of new and regenerated forms of nitrogen in primary productivity. Limnol Oceanogr 12:196-206

Eppley RW, Peterson BJ (1979) Particulate organic matter flux and planktonic new production in the deep ocean. Nature 282:677-680

Gundersen KR, Corbin JS, Hanson CL, Hanson ML and others (1976) Structure and biological dynamics of the oligotrophic ocean photic zone off the Hawaiian Islands. Pac Sci 30:45-68

Holl CM, Waite AM, Pesant S, Thompson PA, Montoya JP (2007) Unicellular diazotrophy as a source of nitrogen to Leeuwin Current coastal eddies. Deep-Sea Res II 54: 1045-1054

Karl DM (2002) Nutrient dynamics in the deep blue sea. Trends Microbiol 10:410-418

> Karl DM (2007) Microbial oceanography: paradigms, processes and promise. Nat Rev Microbiol 5:759-769

Karl DM, Björkman KM (2002) Dynamics of DOP. In: Hansell D, Carlson C (eds) Biogeochemistry of marine dissolved organic matter. Elsevier Science, New York, p 246-366

Karl DM, Tien G (1992) MAGIC: a sensitive and precise method for measuring dissolved phosphorus in aquatic environments. Limnol Oceanogr 37:105-116

> Karl DM, Tien G (1997) Temporal variability in dissolved phosphorus concentrations in the subtropical North Pacific Ocean. Mar Chem 56:77-96

Karl DM, Yanagi K (1997) Partial characterization of the dis- 
solved organic phosphorus pool in the oligotrophic North Pacific Ocean. Limnol Oceanogr 42:1398-1405

Karl DM, Letelier R, Tupas L, Dore J, Christian J, Hebel D (1997) The role of nitrogen fixation in biogeochemical cycling in the subtropical North Pacific Ocean. Nature 388:533-538

Karl DM, Bidigare RR, Letelier RM (2001) Long-term changes in plankton community structure and productivity in the North Pacific Subtropical Gyre: the domain shift hypothesis. Deep-Sea Res II 48:1449-1470

Karl D, Michaels A, Bergman B, Capone D and others (2002) Dinitrogen fixation in the world's oceans. Biogeochemistry 57-58:47-98

Kustka A, Sanudo-Wilhelmy S, Carpenter EJ, Capone DG, Raven JA (2003) A revised estimate of the iron use efficiency of nitrogen fixation, with special reference to the marine cyanobacterium Trichodesmium spp. (Cyanophyta). J Phycol 39:12-25

Letelier RM, Karl DM, Abbott MR, Bidigare RR (2004) Light driven seasonal patterns of chlorophyll and nitrate in the lower euphotic zone of the North Pacific Subtropical Gyre. Limnol Oceanogr 49:508-519

Mague TH, Mague FC, Holm-Hansen O (1977) Physiology and chemical composition of nitrogen-fixing phytoplankton in the Central North Pacific Ocean. Mar Biol 41:213-227

Mahaffey C, Michaels AF, Capone DG (2005) The conundrum of marine $\mathrm{N}_{2}$ fixation. Am J Sci 305:546-595

Michaels AF, Bates NR, Buesseler KO, Carlson CA, Knap AH (1994) Carbon-cycle imbalances in the Sargasso Sea. Nature 372:537-540

Editorial responsibility: Douglas Capone,

Los Angeles, California, USA
Michaels AF, Olson D, Sarmiento JL, Ammerman JW and others (1996) Inputs, losses and transformations of nitrogen and phosphorus in the pelagic North Atlantic Ocean. Biogeochemistry 35:181-226

> Mills MM, Ridame C, Davey M, LaRoche J, Geider RJ (2004) Iron and phosphorus co-limit nitrogen fixation in the eastern tropical North Atlantic. Nature 429:292-294

Montoya JP, Voss M, Kahler P, Capone DG (1996) A simple, high-precision, high-sensitivity tracer assay for $\mathrm{N}_{2}$ fixation. Appl Environ Microbiol 62:986-993

Montoya JP, Holl CM, Zehr JP, Hansen A, Villareal TA, Capone DG (2004) High rates of $\mathrm{N}_{2}$ fixation by unicellular diazotrophs in the oligotrophic Pacific Ocean. Nature 430:1027-1031

Saino T, Hattori A (1980) ${ }^{15} \mathrm{~N}$ natural abundance in oceanic suspended particulate matter. Nature 283:752-754

Sañudo-Wilhelmy SA, Kustka AB, Gobler CJ, Hutchins DA and others (2001) Phosphorus limitation of nitrogen fixation by Trichodesmium in the central Atlantic Ocean. Nature 411:66-69

Wu J, Boyle E, Sunda W, Wen LS (2001) Soluble and colloidal iron in the oligotrophic North Atlantic and North Pacific. Science 293:847-849

Zehr JP, Mellon MT, Zani S (1998) New nitrogen-fixing microorganisms detected in oligotrophic oceans by amplification of nitrogenase (nifH) genes. Appl Environ Microbiol 64:3444-3450

Zehr JP, Waterbury JB, Turner PJ, Montoya JP and others (2001) Unicellular cyanobacteria fix $\mathrm{N}_{2}$ in the subtropical North Pacific Ocean. Nature 412:635-638

Submitted: September 10, 2007; Accepted: May 12, 2008

Proofs received from author(s): July 24, 2008 